\title{
The effect of ensiling and haymaking on the concentrations of steroidal saponin in two Brachiaria grass species
}

\author{
O efeito da ensilagem e fenação sobre as concentrações de saponina esteroide em duas espécies de \\ gramínea Brachiaria
}

\author{
Flavia Gontijo de Lima $^{\mathrm{I}^{*}}$ Stephen Thomas Lee ${ }^{\mathrm{II}}$ James Alan Pfister ${ }^{\mathrm{II}}$ Eliane Sayuri Miyagi \\ Gustavo Lage Costa ${ }^{\mathrm{I}}$ Roberta Dias da Silva ${ }^{\mathrm{I}}$ Maria Clorinda Soares Fioravanti ${ }^{\mathrm{I}}$
}

\begin{abstract}
Brachiaria (signalgrass) is now the most widely used tropical grass genus in Central and South America. However, Brachiaria spp. can cause hepatogenous photosensitization in livestock. Steroidal saponins, specifically protodioscin, present in Brachiaria spp. may be responsible for liver injury and subsequent photosensitization. The objective of this study was to determine the effect of ensiling Brachiaria decumbens and Brachiaria brizantha or making hay from Brachiaria decumbens on the concentrations of steroidal saponin in these grasses. Brachiaria grass had no detectable levels of the saponin protodioscin after 24 days of ensiling. In addition, in Brachiaria decumbens, the concentration of the protodioscin decreased $48 \%$ over the first three days after haymaking and then remained constant. These results suggest that livestock consuming Brachiaria either as silage or hay may have reduced risk of intoxication by protodioscin.
\end{abstract}

Key words: haymaking, hepatogenous photosensitization, saponin, protodioscin, signalgrass, silage.

\section{RESUMO}

Brachiaria atualmente é o gênero de gramínea tropical mais amplamente utilizado na América Central e do Sul. Entretanto, as espécies de Brachiaria podem causar fotossensibilização hepatógena em animais de produção. Saponinas esteroides, especificamente protodioscina, presentes em Brachiaria, podem ser responsáveis pelo dano hepático e consequentemente fotossensibilização. $O$ objetivo deste estudo foi determinar o efeito da ensilagem de Brachiaria decumbens e Brachiaria brizantha e fenação de Brachiaria decumbens sobre a concentração de saponina esteroide. As amostras de Brachiaria ensiladas não tiveram concentrações detectáveis de saponina protodioscina depois de 24 dias de ensilagem. Assim como em Brachiaria decumbens, a concentração de protodioscina reduziu 48\% nos três primeiros dias após a fenação e posteriormente manteve-se constante. Estes resultados sugerem que animais de produção, ao consumirem Brachiaria tanto como silagem ou feno, podem ter o risco de intoxicação por protodioscina reduzido.

Palavras-chave: fenação, fotossensibilização hepatógena, saponina, protodioscina, braquiária, silagem.

\section{INTRODUCTION}

In most parts of the world, forage conservation is a key element for productive and efficient ruminant livestock operations. Forage conservation methods such as ensiling and haymaking allow a more reliable supply of quality feed when forage production is low or dormant (MUCK \& SHINNERS, 2001).

In tropical and subtropical countries, techniques for making silages from forages and by-products are continually improving, and it is probable that the importance of silage will increase, particularly in areas where the markets for milk and milk products are well developed (WILKINS, 2005). Silage represents a convenient and economical source of feed for the dairy and the beef industry. Haymaking also offers a number of advantages: harvesting can largely be mechanized; hay stores well when adequately protected; and hay can meet the nutritional requirements of most classes of livestock (BALL et al., 1991).

Brachiaria spp. (signalgrass) is now the most widely used tropical grass genus, especially in

\footnotetext{
IUniversidade Federal de Goiás (UFG), 74001-970, Goiânia, GO, Brasil. E-mail: flaviamedvet@yahoo.com.br. *Corresponding author.

IUnited States Department of Agriculture (USDA), Poisonous Plant Research Laboratory, Logan, Utah 84341, USA. Received 09.03.14 Approved 10.05.14 Returned by the author 01.23.15 
Central and South America. In Brazil alone, about 40 million hectares of Brachiaria pastures have been planted, more than $85 \%$ of which consist of B. decumbens cv. 'Basilisk' and B. brizantha cv. 'Marandu' (MILES et al., 1996). Silage and hay made from Brachiaria spp. provide quality feed and adequate nutrition for ruminants (FERNANDES et al., 2001; JAYME et al., 2011).

However, Brachiaria spp. can also cause hepatogenous photosensitization in livestock (BRUM et al., 2007). Steroidal saponins, specifically protodioscin, present in these plants may be responsible for liver injury (CASTRO et al., 2011). Saponins are high-molecular-weight glycosides, consisting of a sugar moiety linked to a triterpene or steroid aglycone (HOSTETTMANN \& MARTSON, 1995). In addition, sporidesmin and other hepatotoxic mycotoxins may act in synergy with the steroidal saponins. These complicating factors may explain the sporadic incidence of poisonings (TOKARNIA et al., 2002).

There is little information available about the effect of ensiling or haymaking on saponin concentrations in Brachiaria spp. Thus, the objective of this study was to determine if ensiling and haymaking would change the levels of saponin in Brachiaria grass species.

\section{MATERIALS AND METHODS}

Silage making

Signal grasses (Brachiaria brizantha and Brachiaria decumbens) were cultivated in the municipality of São Francisco de Goiás, in the state of Goiás, west central Brazil $\left(15^{\circ} 55^{\prime} 51^{\prime \prime} \mathrm{S}\right.$, $\left.49^{\circ} 15^{\prime} 39^{\prime \prime} \mathrm{W}\right)$, on a farm of the Federal University of Goiás. The forages were cut for silage 90 days after seeding emergence. Harvested plant material was chopped to $1 \mathrm{~cm}$ by a mechanical harvester and ensiled in small laboratory silos (i.e., plastic bucket) with a 15-liter capacity. A layer of sand and gravel $(4 \mathrm{~kg})$ were placed in the bottom of the silo to drain the effluent. A piece of fabric was placed between the sand and the grass. The fresh forage was introduced into the silos in small amounts and compacted by a manual piston. When completely full the silos were immediately sealed hermetically using a rubber stopper with a Bunsen valve in the center and an additional metallic cover, then stored in a cool and well-ventilated area (VENDRAMINI et al., 2010).

Fresh plants were sampled for saponin analysis before ensiling (Day 0), and after ensiling. The silos were opened on days $4,8,12,16,20$ and
24. A complete randomized design was followed, with a factorial distribution of $2 \times 7$ (grasses $x$ storage period), with three replicates each.

Haymaking

Plots of Brachiaria decumbens were cultivated on the same farm. The forages were cut for haymaking 150 days after seeding emergence. After harvesting, the cut forage was air-dried for three days and then bales $(1 \mathrm{mx} 0.4 \mathrm{mx} 0.3 \mathrm{~m})$ were made mechanically and stored in a well-ventilated barn.

The bales were sampled for saponin analysis (LEE et al., 2009) before haymaking (fresh plant) and on days 1, 2, 3, 4, 5, 6, 7, 8, 14 and 21 after bales were made. There were five replicates for each day and the samples were collected from multiple bales each period, using a $45 \mathrm{~cm}$ drill-type probe that collected a core sample that included exterior and interior material.

\section{Plant preparation}

The samples of $\boldsymbol{B}$. decumbens and $\boldsymbol{B}$. brizantha silage, and $\boldsymbol{B}$. decumbens hay were dried in a forced-air oven at $65^{\circ} \mathrm{C}$ for 72 hours, ground to pass a 2-mm screen in a Wiley mill, and stored in airtight bags at room temperature until analyzed. The plant material stored were dried once more at $105^{\circ} \mathrm{C}$ for 16 hours to the calculation and adjustments to total dry matter.

\section{Extraction}

Extraction of plant material for protodioscin analysis (LEE et al., 2009) was accomplished by weighing $100 \mathrm{mg}$ of ground plant material into a $13 \mathrm{~mL}$ screw top test tube equipped with Teflon lined caps (Pierce, Rockford, IL, USA). Methanol (MeOH, $5 \mathrm{~mL}$ ) was added to each test tube and placed in a mechanical shaker for $30 \mathrm{~min}$, then centrifuged to separate the plant residue and $\mathrm{MeOH}$ extract.

The $\mathrm{MeOH}$ extract was transferred to a clean $20 \mathrm{~mL}$ test tube. The grass residue was extracted two more times with $5 \mathrm{~mL} \mathrm{MeOH}$ for $30 \mathrm{~min}$ and all $\mathrm{MeOH}$ extracts combined for a total of $15 \mathrm{~mL}$. A $0.1 \mathrm{~mL}$ aliquot of the $\mathrm{MeOH}$ extract was transferred to a $1 \mathrm{~mL}$ autosample vial containing $0.9 \mathrm{~mL} 0.1 \%$ formic acid:acetonitrile (90:10) and mixed thoroughly prior to HPLC-ESI-MS analysis.

\section{HPLC-ESI-MS}

Samples were injected $(5 \mu \mathrm{L})$ onto a Betasil C-8 reversed phase column (100x2.1mm i.d.) (Thermo Electron Corporation, Waltham, MA, USA) protected by a guard column of the same phase. The 
total HPLC run time was $3.0 \mathrm{~min}$ with protodioscin eluting at $1.9 \mathrm{~min}$. The saponin was eluted from the column with an isocratic flow $\left(0.500 \mathrm{ml} \mathrm{min}^{-1}\right.$.) of $72: 28(0.1 \%$ formic acid:acetonitrile) mobile phase. Flow from the column was connected directly to a Thermo Finnigan (San Jose, CA USA) LCQ ion trap mass spectrometer via an electrospray ionization (ESI) source. Full scan mass data were collected for a mass range of 300-1300amu. Protodioscin standard (ChromaDex Irvine, CA USA) was prepared in a solution of $0.1 \%$ formic acid:acetonitrile $(90: 10)$ to give a seven point standard curve over the range of $0.78 \mu \mathrm{g} \mathrm{mL}^{-1}-50.0 \mu \mathrm{g} \mathrm{mL}^{-1}$. Peak areas of protodioscin were determined from reconstructed ion chromatograms of the $\mathrm{MH}^{+}-\mathrm{H}_{2} \mathrm{O}$ ions $(m / z=031)$, according to LEE et al. (2009).

\section{Statistical analysis}

Data analyses were performed using SAS/ STAT $^{\circledR}$ software (SAS 2011) by ANOVA procedures for a completely random design in a $2 \times 7$ factorial treatment arrangement, with the factors grass variety and storage.

\section{RESULTS AND DISCUSSION}

Silage was made using both $\boldsymbol{B}$. decumbens and $\boldsymbol{B}$. brizantha, however only $\boldsymbol{B}$. decumbens was used to make hay, because $\boldsymbol{B}$. brizantha hay was previously analyzed by LIMA et al. (2012). The protodioscin results were expressed on dry matter basis. The levels of protodioscin in both Brachiaria spp. rapidly decreased after ensiling. The concentration of protodioscin in $\boldsymbol{B}$. brizantha decreased from $1.41 \pm 0.92 \mathrm{~g} \mathrm{~kg}^{-1}$ on Day 0 (fresh plant) to $0 \mathrm{~g} \mathrm{~kg}^{-1}$ after 4 days $(\mathrm{P}<0.01)$. The concentration of protodioscin in B. decumbens also decreased by $94 \%$ from $2.28 \pm 1.04 \mathrm{~g} \mathrm{~kg}^{-1}$ to $0.14 \pm 0.23 \mathrm{~g} \mathrm{~kg}^{-1}(\mathrm{P}<0.01)$ over the first 4 days and then decreased to $0 \mathrm{~g} \mathrm{~kg}^{-1}$ over the next 20 days (Figure 1).

The concentration of protodioscin in fresh B. decumbens was $10.6 \pm 0.25 \mathrm{~g} \mathrm{~kg}^{-1}$ and this decreased by approximately $48 \%$ after 3 days as hay $(\mathrm{P}<0.01)$. For the next 5 days (Day 3 to 8 ) the concentration remained relatively constant at approximately 5.5-7.3 $\mathrm{g} \mathrm{kg}^{-1}(\mathrm{P}<0.01)$, then had a light increase to

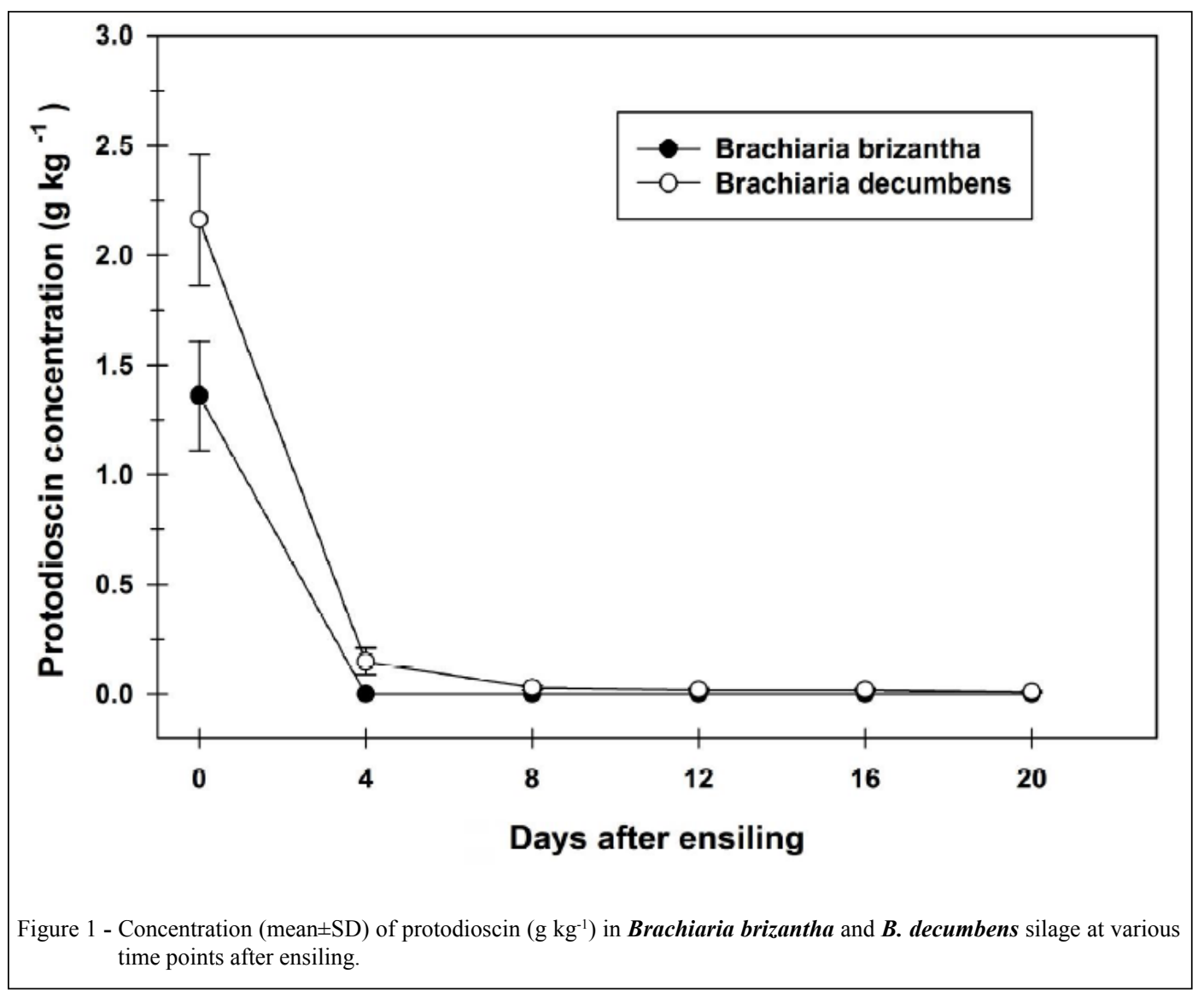

Ciência Rural, v.45, n.5, mai, 2015. 
$8.67 \pm 0.64 \mathrm{~g} \mathrm{~kg}^{-1}$ on Day $14(\mathrm{P}>0.01)$ and $8.24 \pm 1.31 \mathrm{~g}$ $\mathrm{kg}^{-1}$ on Day $21(\mathrm{P}<0.01)$, in comparison to the fresh plant (Figure 2).

Protodioscin in Brachiaria brizantha and $\boldsymbol{B}$. decumbens was degraded under the silage conditions employed in this study. Similar research has been performed with alfalfa silage And KALAC et al. (1996) measured saponin changes in alfalfa over 7 and 90 days of ensilage, and saponin losses ranged from $38 \%$ to $100 \%$ depending on the specific saponin. OLIVEIRA et al. (2003) also reported saponin degradation of $55-90 \%$ in alfalfa silage over 33 days. In addition, PINOS-RODRIGUEZ et al. (2008; 2009) also found that ensiling Agave salmina led to reductions in saponin levels.

Harvesting forage initiates a complex chain of events that can affect quality and concentrations of secondary compounds. Forage quality declines during the post-harvest phase because plant enzymatic activity and microbial growth continue (MOSER, 1980). Aerobic respiration may result in the loss of some sugars in the first stage of the ensiling process. The second stage involves anaerobic bacterial action and the fermentation reactions of the ensiling process, when carbohydrate fermentation occurs (MOSER, 1980).

Losses of sugars during hay wilting and the first step of ensiling, by plant respiration and microbial growth could explain the reduction of protodioscin in the present study. The typical steroidal saponin molecule has an aglycone or non-saccharide portion (sapogenin) attached to one or more sugar chains containing glucose, galactose, xylose, arabinose, rhamnose or glucuronic acid (HOSTETTMANN \& MARSTON, 1995; WINA et al., 2005). The extensive enzymatic activity could explain the decrease in the level of intact saponins, by the cleavage of the sugar side chains (KALAC et al., 1996).

In a previous study, LIMA et al. (2012) found that the haymaking process and storage reduced the levels of protodioscin in Brachiaria brizantha samples by about $46 \%$. The amount of protodioscin in the fresh plant was of $18.7 \mathrm{~g} \mathrm{~kg}^{-1}$ in contrast to $8.6 \mathrm{~g} \mathrm{~kg}^{-1}$ in the hay. Their results in hay are similar to the $48 \%$ reduction in protodioscin concentration observed after Day 3 of Brachiaria decumbens hay in this study.

The reduction of saponin during wilting in haymaking calls into question the methodology of studies that quantified steroidal saponins in grasses. There is no standardized methodology for drying grass samples before analysis. Several experiments have dried grass samples using various methods: air-drying, drying at room temperature, freezedrying, or drying in a forced-air oven. Furthermore,

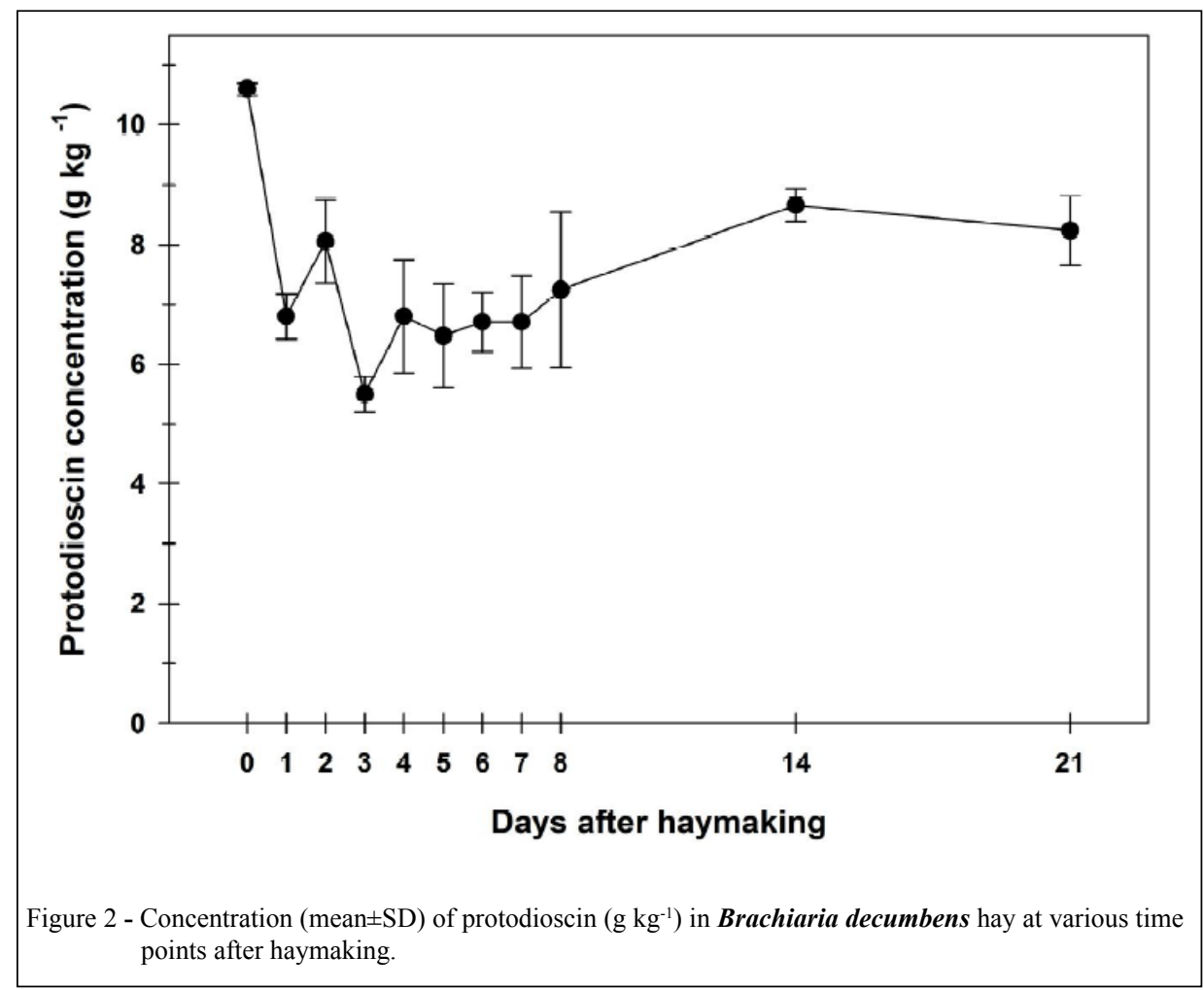

Ciência Rural, v.45, n.5, mai, 2015. 
some studies do not report the drying method used (BRUM et al., 2007; CASTRO et al., 2011). For this reason, the amount of steroidal saponins described in the current literature may be underestimated when compared to the fresh plant and with what animals are really being fed. Studies are needed to determine the effect of drying method on quantification of steroidal saponins.

The spores of Pithomyces chartarum fungus can contain the hepatotoxic sporidesmin that can cause hepatogenous photosensitization like Brachiaria poisoning. P. chartarum normally produces sporidesmin, but some strains do not produce sporidesmin. Most researchers agree that the isolated forms of New Zealand and Australia produce more sporidesmin than that from the Americas. LEMOS et al. (1996) examined 30 isolated cases of $\boldsymbol{P}$. chartarum from $\boldsymbol{B}$. decumbens with a history of outbreaks in sheep in Brazil, and only one isolate produced sporidesmin. They concluded that the disease was caused by $\boldsymbol{B}$. decumbens and not by the toxin from the fungus. COLLIN et al. (1998) evaluated 51 isolates of $\boldsymbol{P}$. chartarum, including 9 samples from Brazil, only a single Brazilian sample produced sporidesmin $(2 \%)$, while isolates from New Zealand produced 86\% (391), from Australia 67\% (207) and from Uruguay 28\% (182). HALDER et al. (1981) analyzed samples from North America, and did not observe the production of sporidesmin. DNA analysis proved that the strains producing sporidesmin from New Zealand are different than those non-producing from South Africa and the Americas (BEEVER and PARKER, 1993). Until now, there is not a strong evidence that strains from Brazil produce sporidesmin and the causes of hepatogenous photosensitization are mainly attributed to Brachiaria poisoning.

The periodic incidence of liver toxicity in ruminants grazing on Brachiaria spp. pasture is problematic. However, the use of ensiling and haymaking to preserve Brachiaria forage may reduce the incidence of toxicity in ruminants fed with these prepared forages compared to ruminants grazing on Brachiaria pastures. Animal toxicity studies will be necessary to verify these results for the livestock industry.

\section{CONCLUSION}

The process of ensiling and making hay reduced the levels of the steroidal saponin protodioscin in Brachiaria brizantha silage and in Brachiaria decumbens silage and hay.

\section{ACKNOWLEDGEMENTS}

This study was made possible by grants from the Brazilian Federal Agency for Support and Evaluation of Graduate Education (CAPES) and the Brazilian National Council for Scientific and Technological Development (CNPq). The authors wish to thank Tayrone F. Prado, Weyguer C. Fernandes, Helton F. Oliveira and Sharon Azzopardi for their technical support.

\section{REFERENCES}

BALL, D.M. et al. Southern forages. Atlanta: Potash \& Phosphate Institute (PPI) and Foundation for Agronomic Research (FAR), 1991. 264p.

BEEVER, R. E.; PARKES, S. L. Variation of Pithomyces chartarum, causal agent of facial eczema. Proceedings of a Symposium on Mycotoxicosis of Grassland Farming. New Zealand Veterinary Journal, Palmerston North, v. 41, n. 4, p. 212-224, 1993.

BRUM, K.B. et al. Crystal-associated cholangiopathy in sheep grazing Brachiaria decumbens containing the saponin protodioscin. Pesquisa Veterinária Brasileira, Rio de Janeiro, v.27, n.1, p.39-42, 2007. Avaliable from: <http://dx.doi. org/10.1590/S0100-736X2007000100007>. Accessed on: nov. 15, 2014. doi: 10.1590/S0100-736X2007000100007.

CASTRO, M.B. et al. Brachiaria spp. poisoning in sheep in Brazil: experimental and epidemiological findings. In: RIETCORREA et al. Poisoning by plants, mycotoxins, and related toxins. Wallingford: CAB International, 2011. Cap.15, p.110-117.

COLLIN, R.G. et al. Sporidesmin production by Pithomyces chartarum isolates from Australia, Brazil, New Zealand and Uruguay. Mycological Research, v.102, n.2, p.163-166, 1998. Avaliable from: $<$ http://www.sciencedirect.com/science/article/pii/ S0953756208608503>. Accessed on: nov. 15, 2014. doi: 10.1017/ S0953756297004905.

FERNANDES, L.O. et al. Quality of ammoniated Brachiaria decumbens hay. Piracicaba, SP, Brazil, 2001. In: GOMIDE, J.R. et al. INTERNATIONAL GRASSLAND CONGRESS, 19., 2001, Piracicaba, SP, Brazil. Proceedings... Piracicaba: International Grassland Congress, 19., 2001. p.779-780.

HALDER, C.A. et al. Absence of Sporidesmin production by twelve Texas isolates of Pithomyces spp. Applied and Environmental Microbiology, v.41, n.1, p.212-215, 1981. Available from: < http:// aem.asm.org/content/41/1/212>. Accessed on: nov. 15, 2014.

HOSTETTMANN, K.; MARSTON, A. Saponins: chemistry and pharmacology of natural products. Cambridge: Cambridge University, 1995. 549p.

JAYME, C.G. et al. Consumo e digestibilidade aparente de silagens de Brachiaria brizantha cv 'marandu' adicionada de aditivos. Arquivo Brasileiro de Medicina Veteterinária e Zootecnia. Belo Horizonte, v.63, n.3, p.704-711, 2011. Available from: <http:// dx.doi.org/10.1590/S0102-09352011000300023>. Accessed on: nov. 15 2014. doi: 10.1590/S0102-09352011000300023.

KALAC, P. et al. Changes in saponin content and composition during the ensilage of alfalfa (Medicago sativa L.). Food 
Chemistry, v.56, n.4, p.377-380, 1996. Avaliable from: <http:// dx.doi.org/10.1016/0308-8146(95)00185-9>. Accessed on: nov. 15 2014. doi: 10.1016/0308-8146(95)00185-9.

LEE, S.T. et al. Isolation, characterization, and quantification of steroidal saponins in switchgrass (Panicum virgatum L.). Journal of Agricultural and Food Chemistry, v.57, p.2599-2604, 2009. Avaliabre from: <http://pubs.acs.org/doi/abs/10.1021/jf803907y $>$. Acessed on: nov. 15, 2014. doi: 10.1021/jf803907y.

LEMOS, R.A.A. et al. Fotossensibilização e colangiopatia associada a cristais em ovinos em pastagem com Brachiaria decumbens. Ciência Rural, v.26, n.1, p.109-113, 1996. Avaliable from: <http:// dx.doi.org/10.1590/S0103-84781996000100020>. Acessed on: nov. 15 , 2014. doi: 10.1590/S0103-84781996000100020.

LIMA, F.G. et al. Effects of Brachiaria hay containing steroidal a saponin in lambs. International Journal of Poisonous Plant Research, v.2, p.20-26, 2012.

MILES, J.W. et al. Brachiaria: biology, agronomy and improvement. Cali: International Center of Tropical Agriculture, 1996. 303p.

MOSER, L.E. Quality of forage as affected by post-harvest storage and processing. In: HOVELAND, C.S. Crop quality, storage, and utilization. Madison: American Society of Agronomy, Crop Science Society of America, 1980. p.227-259.

MUCK, R.E.; SHINNERS K.J. Conserved forage (silage and hay): progress and priorities. Piracicaba, SP, Brazil, 2001. In: GOMIDE, J.R. et al. INTERNATIONAL GRASSLAND CONGRESS, 19., 2001, Piracicaba, SP, Brazil. Proceedings... Piracicaba: International Grassland Congress, 19., 2001. p.753762 .

OLIVEIRA, M.A. et al. Influência da ensilagem no teor de saponinas de luzerna (Medicago sativa L.). Pastagens e
Forragens, v.24, p.45-56, 2003. Avaliable from: <http://sppf.pt/ rubricas/pf_24-25.pdf>. Accessed on: nov. 15, 2014.

PINOS-RODRIGUEZ, J.M. et al. The effect of plant age on the chemical composition of fresh and ensiled Agave salmiana leaves. South Africa Journal of Animal Science, v.38, n.1, p.43-50, 2008. Avaliable from: <http://www.sasas.co.za/effect-plant-agechemical-composition-fresh-and-ensiled-agave-salmiana-leaves $>$. Accessed on: nov. 15, 2014

PINOS-RODRIGUEZ, J.M. et al. Effects of maturity and ensiling of Agave salmiana on nutritional quality for lambs. Animal Feed Science and Technology, v.152, n.3-4, p.298-306, 2009. Avaliable from: $<$ http://dx.doi.org/10.1016/j.anifeedsci.2009.05.002>. Accessed on: nov. 15, 2014. doi: 10.1016/j.anifeedsci.2009.05.002.

TOKARNIA, H.C. et al. Poisonous plants affecting livestock in Brazil. Toxicon, v.40, n.12, p.1635-1660, 2002. Avaliable from: $<$ http://dx.doi.org/10.1016/S0041-0101(02)00239-8>. Accessed on: nov. 15, 2014. doi: 10.1016/S0041-0101(02)00239-8.

SAS. SAS/STAT ${ }^{\circledR}$ software, SAS 9.3. 2ed. Cary: Institute, 2011.

VENDRAMINI, J.M.B. et al. Nutritive value and fermentation parameters of warm season grass silage. Professional Animal Scientist, v.26, n.2, p.193-200, 2010. Avaliable from: <http://pas. fass.org/content/26/2/193>. Accessed on: nov. 15, 2014.

WILKINS, R.J. Silage: a global perspective. In: REYNOLDS, S.G.; FRAME J. Grasslands: developments, opportunities and perspectives. Rome and Plymouth: Food and Agricultural Organization and Science Publishers, 2005. p.111-132.

WINA, E. et al. The impact of saponins or saponin-containing plant materials on ruminant production: a review. Journal of Agricultural and Food Chemistry, v.53, n.21, p.8093-8105, 2005. Avaliable from: <http://pubs.acs.org/toc/jafcau/53/21>. Accessed on: nov. 15, 2014. doi: 10.1021/jf048053d. 